\title{
Fossil calibration dates for molecular phylogenetic analysis of snakes 1 : Serpentes, Alethinophidia, Boidae, Pythonidae
}

\author{
Jason J. Head
}

\begin{abstract}
Snakes possess a dense fossil record through the Late Cretaceous and Cenozoic and are an important clade for studies of molecular phylogenetics. The use of the snake fossil record has historically been a limited and inaccurate source of temporal data in molecular studies due to taxonomic and phylogenetic ambiguities. Here I provide 10 fossil calibration dates for phylogenetic analysis of higher-order interrelationships of snakes. Calibration points include apomorphy-based systematic justifications and precise dates for hard minimum divergence timings. Calibrated nodes are for the snake total clade, Alethinophidia, and boid and pythonid taxa. Hard minimum divergence timings range from earliest late Cretaceous to middle Miocene. These dates provide precise minima for constraining the early evolutionary history of Serpentes. Comparisons of phylogenetically justified calibrations with published studies that employed form-taxon assignments suggests greatly younger divergences for justified nodes and indicates that deep-time divergence estimates that have been correlated with tectonic histories may be considerably too old and reliant on presumptions of Early Cretaceous Gondwanan vicariance as a mechanism of speciation.
\end{abstract}

Jason J. Head. Department of Earth and Atmospheric Sciences and Nebraska State Museum of Natural History University of Nebraska-Lincoln, Lincoln, NE 68588-04340. Jhead2@unl.edu.

Keywords: Serpentes; fossil; calibration; Boidae; Pythonidae; Alethinophidia

\section{INTRODUCTION}

Serpentes has been a common study taxon for molecular phylogenetic analyses, both with respect to its position within Squamata and the interrelationships of constituent subclades (e.g., Heise et al., 1996; Slowinski and Lawson, 2002; Vidal and Hedges, 2002; Wilcox et al., 2002; Vidal and David, 2004; Vidal and Hedges, 2004, 2009; Lawson et al., 2004; Townsend et al., 2004; Bur-

PE Article Number: 18.1.6FC

Copyright: Society for Vertebrate Paleontology April 2015

Submission: 7 May 2014. Acceptance: 20 March 2015

Head, Jason J. 2015. Fossil calibration dates for molecular phylogenetic analysis of snakes 1: Serpentes, Alethinophidia, Boidae, Pythonidae. Palaeontologia Electronica 18.1.6FC; 1-17;

palaeo-electronica.org/content/fc-6

Calibrations published in the Fossil Calibration Series are accessioned into the Fossil Calibration Database (www.fossilcalibrations.org). The Database is a dynamic tool for finding up-to-date calibrations, and calibration data will be updated and annotated as interpretations change. In contrast, the Fossil Calibration papers are a permanent published record of the information on which the calibrations were originally based. Please refer to the Database for the latest data. 
brink, 2005; Gower et al., 2005; Lawson et al., 2005; Noonan and Chippindale, 2006a; Burbrink and Lawson, 2007; Sanders et al., 2010; Wiens et al., 2012; Pyron et al., 2013). The fossil record of snakes has been used to calibrate divergence timings in multiple phylogenies (e.g., Sanders et al., 2010; Pyron and Burbrink, 2012), including studies that have correlated fossil-based divergence timings with geologic and climatic events (Noonan and Chippindale, 2006a, 2006b). Despite this usage, the efficacy of snake fossils for calibration has historically been hampered by the nature of the fossil record and methodological approaches to systematics (see Sanders et al., 2010 for additional discussion).

The majority of the fossil record of snakes consists of isolated or associated precloacal vertebrae (e.g., Rage, 1984; Holman, 2000), and although snakes possess morphologically complex and distinct vertebral morphology relative to other squamates (e.g., Hoffstetter and Gasc, 1969), there is a finite number of discrete apomorphies available from which phylogenetic hypotheses can be inferred from vertebrae. Historically, studies of snake fossils have relied on general similarity, "gestalt" approaches, and spatiotemporal provenance for systematic assignments (see Rage, 1984; Holman, 2000, Bell et al., 2004; Head, 2005; Bell et al., 2010, for examples of application, discussion, and critique). The result of these methods is often the application of phylogenetically explicit clade names and identities to generalized form taxa that have no phylogenetic rationale (e.g., Szyndlar et al., 2008), which can produce widely inaccurate calibration points (e.g., Noonan and Chippindale, 2006a after Parham et al., 2012). Additionally, many extant snake taxa are not recognized in the fossil record (Figure 1), or have first occurrences that greatly postdate divergence timings estimated from the fossil record of sister taxa. Despite these limitations, the fossil record of snakes is dense and continuous from the Late Cretaceous on, and thus is an important datum for constraining the historical relationship between environmental change and biological evolution for a diverse and important vertebrate clade.

Here I provide a set of fossil calibration points for snake phylogeny, following the guidelines of Parham et al. (2012). Despite a long history of pronounced discordance between morphological and molecular phylogenetic hypotheses of Serpentes (e.g., Lee and Scanlon, 2002; Slowinski and Lawson, 2002; Wiens et al., 2010; Gauthier et al., 2012), fossils can be placed in molecular topolo- gies where there is congruence in clade composition and discrete apomorphies can be identified for fossil specimens. As a result, the fossil record of snakes can be used to temporally calibrate molecular nodes (Figure 1). Molecular phylogenetic topologies are generally consistent for higher-order snake clades, but several crucial nodes, including the sister taxon to Serpentes, as well as the relationships of "aniliods", are controversial or poorly resolved between molecular studies (e.g, Wilcox et al., 2002; Vidal and Hedges, 2004; Gower et al., 2005; Reynolds et al., 2014). Except where noted, referred divergences are from the most recent and comprehensive molecular phylogenetic analyses (Pyron et al., 2013; Reynolds et al., 2013, 2014). This set of calibrations is the first of two, and focuses on the oldest Mesozoic and Paleogene calibration points, as well as calibrations for boid and pythonid taxa (sensu McDiarmid et al., 1999). Calibration dates for Caenophidia, the majority of snake diversity, will compose the second set.

\section{Institutional Abbreviations}

DGM, Departamento Nacional de Produção Mineral, Rio de Janeiro, Brazil; HJU-PAL EJ, Hebrew University of Jerusalem, Paleontological Collections, Jerusalem, Israel; MCZ, Museum of Comparative Zoology, Harvard University, Massachusetts, USA; MML-PV, Museo Municipal de Lamarque, Rio Negro, Argentina; MNHN, Muséum national d'Historie Naturelle, Paris, France; OMNH, Oklahoma Museum of Natural History, Oklahoma, USA; PTRM, Pioneer Trails Regional Museum, North Dakota, USA; QM F, Queensland Museum, Queensland, Australia; UF/IGM, University of Florida, Instituto Nacional de Investigaciones Geologico-Mineras, Bogota, Colombia; UNSM, University of Nebraska State Museum, Nebraska, USA.

\section{PAN-SERPENTES}

Node Calibrated. Divergence between the total clade of Serpentes and its nearest crown sister taxon: Iguania, Anguimorpha, or (Iguania+Anguimorpha).

Fossil Taxon. "Coniophis sp." (Gardner and Cifelli, 1999), best regarded as "Pan-Serpentes indeterminate."

Specimen. OMNH 33520, isolated precloacal vertebra.

Additional Materials. OMNH 33521, isolated precloacal vertebra.

Phylogenetic Justification. Both specimens possess unambiguous apomorphies of all known total clade Serpentes, including a well-developed zygo- 


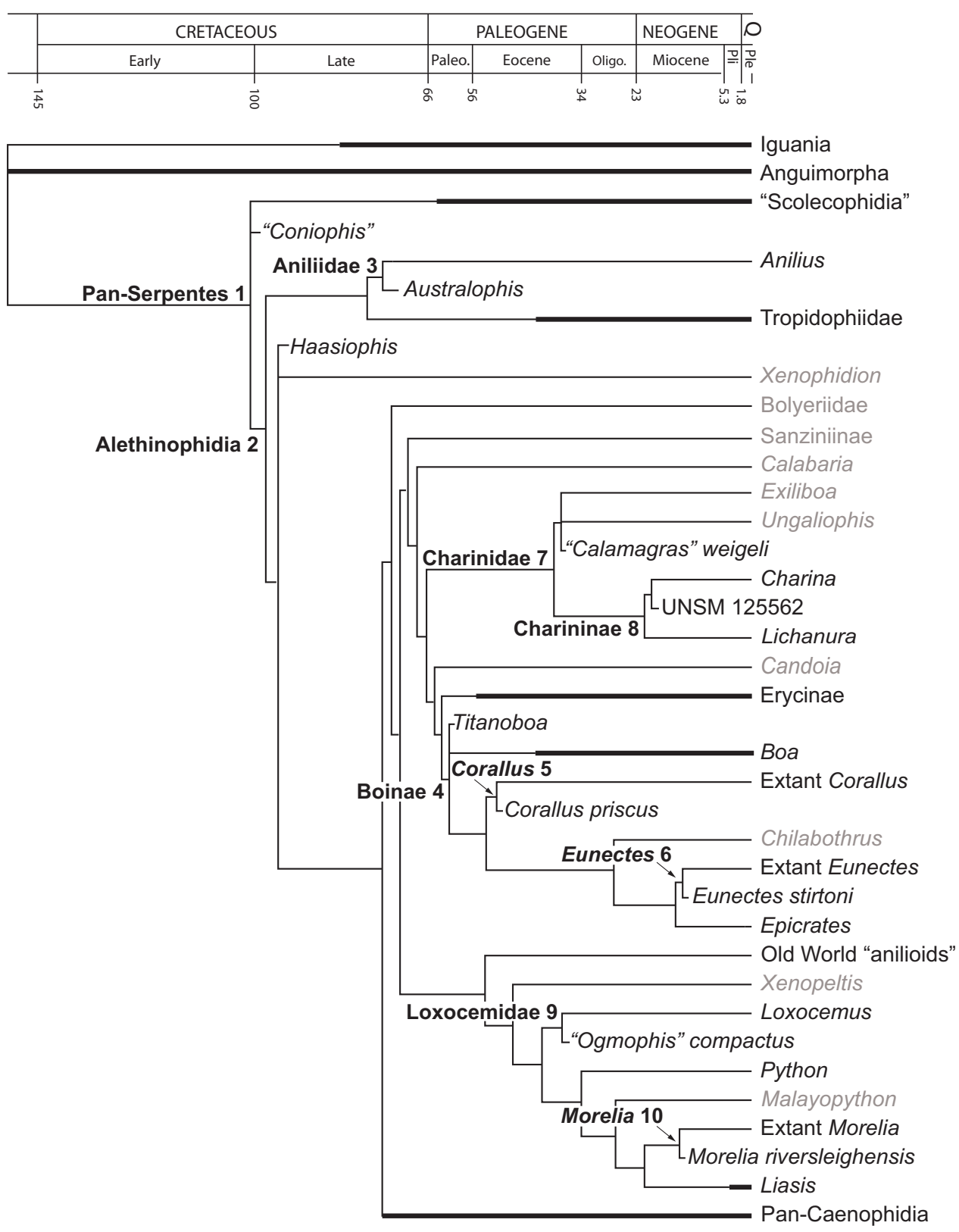

FIGURE 1. Time-calibrated phylogeny of Serpentes based on Pyron et al. (2013) and Reynolds et al. (2014). Numbers represent calibrated nodes in text. Fossil taxa are the calibration points for their respective nodes. Thickened bars represent well-sampled, taxonomically resolved stratigraphic distributions for the sister taxa to Pan-Serpentes and snake lineages whose first occurrences are determined by older sister taxa. Thin bars represent estimated stratigraphic distributions for taxa with poorly resolved fossil records, or no published fossil record (names in grey). "Scolecophidia" represents a paraphyletic grade with respect to Alethinophidia (see text).

sphene-zygantral articulation consisting of a transversely wide zygosphene with dorsolaterally angled articular facets and a medially convex anterior margin, and a deep zygantrum with distinct ventromedially angled articular facets. Additional characters include synapophyses with distinct para- and diapophyseal articular surfaces, and well-developed intergyapophyseal ridges. These characters do not differentiate between crown and stem taxa, and there are no diagnostic characters present, or defined, for Coniophis (see below).

Minimum Age. 98.32 Ma (98.39 $\pm 0.07 \mathrm{Ma}$, Cifelli et al., 1997), early Cenomanian (Ogg et al., 2012). Soft Maximum Age. $\sim 113 \mathrm{Ma}$, Aptian-Albian boundary (Ogg et al., 2012). 
Age Justification. Both specimens were collected in the uppermost Cedar Mountain Formation (Mussentuchit Member), Emery County, Utah. The Cedar Mountain Formation spans the Early Cretaceous and Early-Late Cretaceous transition (Cifelli et al., 1997). ${ }^{40} \mathrm{Ar} /{ }^{39} \mathrm{Ar}$ dating of Sanidine phenocrysts from smetitic ash horizons directly overlying snake-bearing fossil localities produced a weighted mean age of $98.39 \pm 0.07 \mathrm{Ma}$, which is used as the hard minimum age for Serpentes. The soft maximum age is based on uncertainty in age estimates for late Albian snakes from Algeria (see discussion below).

Discussion. Gardner and Cifelli (1999) assigned the specimens to Coniophis on the basis of seven characters they considered diagnostic for the genus. The majority of the listed characters are either plesiomorphic for Serpentes (e.g., absence of prezygapophyseal accessory processes), or characteristic of fossorial ecomorphology (reduction of neural spine, absence of posteromedian notch, high-angled prezygapophyses). Only a single vertebral apomorphy has been proposed for Coniophis, a deep, ovate paracotylar fossae (Longrich et al., 2012), but this feature is present in a wide variety of taxa (e.g., Rage, 1984). Specimens assigned to Coniophis have been considered either "anilioids" (e.g., Hecht, 1959), or stem snakes (Longrich et al., 2012), but the Cedar Mountain record is not informative on the systematic relationships of "Coniophis". Similarly, the lack of phylogenetic resolution of the Cedar Mountain record limits calibration to a minimum age for Serpentes relative to the most closely related crown taxon and not calibrations within the clade.

The oldest fossil records of potential sister taxa to Pan-Serpentes provide disparate alternate calibrations from the oldest snake record. Current molecular phylogenies place Serpentes with Anguimorpha and Iguania (e.g., Townsend et al., 2004; Vidal and Hedges, 2005; Pyron et al., 2013) in the clade Toxicofera (Vidal and Hedges, 2005). Interrelationships of the three clades within Toxicofera include moderately supported monophyly of (Iguania+Anguimorpha) or (Anguimorpha+Serpentes) (Pyron et al., 2013). Numerous Mesozoic fossils have been referred to Anguimorpha; however, only Dorsetisaurus from the Lulworth Formation (Early Cretaceous, Berriasian) is consistently recognized as anguimorph (e.g., Hoffstetter, 1967; Evans, 1994; Evans et al., 2005; Conrad, 2008; Conrad et al., 2011). If either of the aforementioned phylogenetic hypotheses within Toxicofera is accurate, then the occurrence of Dorsetisaurus mini- mally extends the age of the snake total clade to approximately $145 \mathrm{Ma}$ at the base of the Berriasian. Assignment of late Jurassic specimens from North America to Dorsetisaurus is based on tooth crown morphology (Evans and Chure, 1998), whereas the Berriasian-aged type specimen of the genus is based on a taxonomically definitive skull (Hoffstetter, 1967). If further discovery provides more robust assignment of Tithonian-aged fossils to the taxon, then the calibrated age of Pan-Serpentes would be extended to 152 Ma.

Conversely, if Iguania is the sister-taxon to Pan-Serpentes, then the first occurrence of the snake total clade may approximate the age of Cedar Mountain Formation record. The Early Cretaceous (Barremian, 131 Ma) Hoyalacerta (Evans and Barbadillo, 1999) has been considered either a stem squamate or stem iguanian (Evans and Barbadillo, 1999; Conrad, 2008; Bolet and Evans, 2011), but the oldest unambiguous iguanians are recovered from the Late Cretaceous (Campanian, >4 Ma) of Asia (e.g., Gao and Hou, 1995; Gao and Norell, 2000; Conrad and Norell, 2007; Alifanov, 2013), approximately 16 Ma younger than the oldest fossil record of Pan- Serpentes.

Lack of phylogenetic consensus within Toxicofera combined with great differences in first occurrence dates between Anguimorpha and Iguania result in potential temporal range extensions for Pan-Serpentes from $52 \mathrm{Ma}$ to $0 \mathrm{Ma}$ older than the Cedar Mountain Formation record. The "Coniophis" record described here is used to calibrate the snake total clade due to systematic ambiguity within Toxicofera and the absence of any definitive Early Cretaceous, but with the explicit recognition that a resolved sister taxon relationship between either Serpentes and Anguimorpha or Iguania and Anguimorpha requires a much older first occurrence for Pan-Serpentes.

If the "Coniophis" record falls within the crown Serpentes, then it predates the first occurrence of constituent clades by only $\sim 4 \mathrm{Ma}$, based on the minimum age for the first occurrence of Alethinophidia (see below). Scolecophidia, the clade including Typhlopidae, Leptotyphlopidae and Anomalepididae, has been rendered paraphyletic in early and recent molecular analyses (Heise et al., 1996; Wiens et al., 2012). The oldest fossil records referred to scolecophidians are ?Anomalepididae from the Tornillo Formation (early Paleocene, Puercan $\sim 65 \mathrm{Ma}$ ) of Texas (Standhardt, 1986; Schiebout et al., 1987), and Scolecophidia indet. from the late Paleocene of Morocco (Augé and Rage, 2006). Temporal differences between these 
records and the calibrations for Pan-Serpentes and Alethinophidia (see below) indicate unrecovered histories of $\sim 28-45 \mathrm{Ma}$ for Scolecophidia sensu lato (Figure 1).

The radiometric dates of the uppermost Cedar Mountain Formation provide the most accurate precise minimum age for the snake total clade, but older records have been reported. Hoffstetter (1959) described Lapparentophis defrennei from the Akhamil (Albian) of Algeria, but Akhamil has been reassessed as being either latest Albian or early Cenomanian (Cuny et al., 1990), approximately coeval with the Cedar Mountain record. Cuny et al. (1990) described Lapparentopheidae indet. and Serpentes indet. from El Kohol in Algeria, and reported the age of the specimens as late Albian. No evidence was provided for this age estimate, however. Other Cenomanian snake records include the marine pachyostotic taxa Pachyrhachis, Haasiophis, Eupodophis, Mesophis, Pachyophis, and Simoliophis from North Africa, Europe, and the Middle East (e.g., Nopcsa, 1923, 1925; Bolkay, 1925; Haas, 1979, 1980; Nessov et al., 1998; Tchernov et al., 2000; Rage and Escuillié, 2000, 2003), as well as the terrestrial taxon Pouitella and indeterminate or stem snakes from France (Rage, 1988; Vullo et al., 2011) and Brazil (Hsiou et al., 2009, 2014). All of these records have been estimated to be early to middle Cenomanian, in age, but are less temporally constrained than the Cedar Mountain record. A diverse snake fauna including madtsoiids, nigerophiids, palaeopheids, and Colubroidea from the Wadi Milk Formation of Sudan was originally estimated as Cenomanian in age (Rage and Werner, 1999), but is currently considered Maastrichtian (J. Müller, personal commun., 2013).

\section{CROWN ALETHINOPHIDIA}

Node Calibrated. Divergence between total clade (Aniliidae +Tropidophiinae) and total clade Macrostomata.

Fossil Taxon. Haasiophis terrasanctus Tchernov et al., 2000.

Specimen. HJU-PAL EJ 695, complete skeleton. Phylogenetic Justification. Haasiophis is placed within Alethinophidia as either a stem or crown macrostomatan on the basis of numerous characters including (but not limited to): quadrate suspended from free-ending process of the supratemporal; anterior dentigerous process of palatine; "alethinophidian type" (Zaher and Rieppel, 1999) tooth attachment; and loss of pre- maxilla-maxillary articulation (e.g., Tchernov et al., 2000; Gauthier et al., 2012).

Minimum Age. $93.9 \mathrm{Ma}$.

Soft Maximum Age. 100.5 Ma.

Age Justification. Minimum and maximum ages are for the Cenomanian (Ogg et al., 2012). The only specimen of Haasiophis was recovered from the 'Ein Yabrud quarries in the Judean hills, Israel. 'Ein Yabrud is located in either the late Cenomanian Amminadav Formation or underlying early Cenomanian Bet Meir Formation (Chalifa and Tchernov, 1982; Chalifa, 1985; Braun and Hirsch, 1994). Fish biostratigraphy has been used to infer an early Cenomanian age for 'Ein Yabrud as part of the Bet Meir Formation (Chalifa and Tchernov, 1982), but subsequent placement of localities at the base of the Amminadav Formation (Chalifa, 1985; Braun and Hirsch, 1994) suggests a middlelate Cenomanian age, and 'Ein Yabrud is more recently considered early-middle Cenomanian (Tchernov et al., 2000; Rieppel et al., 2003). The age range presented here reflects both the overall uncertainty of the position of 'Ein Yabrud within the Cenomanian, and the absence of any definitive snake fossils globally prior to the earliest Late Cretaceous.

Discussion. Both Haasiophis and Pachyrhachis problematicus are from the same horizon in 'Ein Yabrud (Haas, 1979, 1980) but HJU-PAL EJ 695 is chosen as a calibration point because it is better preserved and more complete than any other single Mesozoic snake specimen.

The systematic relationships of Haasiophis have been controversial. The taxon has been considered a macrostomatan in most morphological phylogenetic analyses of snakes (e.g., Tchernov et al., 2000; Apesteguía and Zaher, 2006; Wilson et al., 2010 [as part of Pachyophiidae]; Longrich et al., 2012; Zaher and Scanferla, 2012). However, other analyses of snake phylogeny have placed Haasiophis along the snake stem based on alternate interpretations of skeletal morphology (Lee and Scanlon, 2002; Scanlon, 2006; Palci et al., 2013). Recent comprehensive analyses of Squamata based on morphology have placed Haasiophis within Alethinophidia as either sister-taxon to (Conrad, 2008) or nested within (Gauthier et al., 2012) Macrostomata. Molecular phylogenetic analyses do not explicitly identify Macrostomata (e.g., Pyron et al., 2013), but Macrostomata is employed here as the total clade of alethinophidians more closely related to each other than any are to (Aniliidae +Tropidophiinae) (e.g., Pyron et al., 2013, figure 21). Combined morphological and molecular 
analysis of Squamata similarly places the taxon within a clade of "macrostomatans" (Wiens et al., 2010), and this topology is employed for calibration with the important caveat that tropidophiines, which possess macrostromatan suspensorial morphology but are sister taxon to Aniliidae in molecular phylogenetic analyses, have not been incorporated in combined analyses.

\section{ANILIIDAE}

Node Calibrated. Divergence between total clades Aniliidae and Tropidophiidae.

Fossil Taxon. Australophis anilioides Gómez et al., 2008.

Specimen. MML-PV181, precloacal vertebra.

Phylogenetic Justification. Assignment to Aniliidae Stejneger, 1907 sensu MacDiarmid et al. (1999) is based on the following apomorphic character combination: low neural arch does not rise much above zygapophyseal plane, neural spine reduced, elongate prezygapophyses that are elongate and high-angled, concave posterior margin of neural arch (Goméz et al., 2008).

Minimum Age. 72.1 Ma (Campanian-Maastrichtian boundary).

Soft Maximum Age. Indeterminate.

Age Justification. The Allen Formation is dated as late Campanian-Early Maastrichtian based on its stratigraphic position overlying the Anacleto Formation and underlying the Jagüel Formation (Gómez et al., 2008). The Anacleto Formation is dated to late Campanian based on magnetostratigraphic correlation to Chron C33R (83.5-79.5 Ma) (Dingus et al., 2000), whereas the Jagüel Formation is dated as mid-Maastrichtian to early Danian based on foraminiferal biostratigraphy (Leanza et al., 2004; Goméz et al., 2008). The horizon within the Allen Formation that produced Australophis specimens is measured at 48 meters below the K$\mathrm{Pg}$ boundary and is considered no younger than early Maastrichtian (Goméz et al., 2008). The exact minimum age provided is for the CampanianMaastrichtian boundary, which is likely to be slightly older than the actual age of the type specimen of Australophis.

Discussion. Molecular phylogenetic analyses consistently recover monophyly of Anilius with Tropidophiinae as the sister taxon to all other alethinophidians (e.g., Wilcox et al., 2002; Gower et al., 2005; Pyron et al., 2013), despite morphological support for tropidophiines being deeply nested macrostomatans and Anilius being nested within a monophyletic Anilioidea as sister taxon to South Asian Cylindrophis, Anomochilus, and Uro- peltinae (e.g., Lee and Scanlon, 2002; Wilson et al., 2010; Gauthier et al., 2012). If future molecular studies corroborate morphological phylogenetic hypotheses then Australophis represents the oldest occurrence of crown group Anilioidea.

The fossil record of aniliids includes specimens from the Late Cretaceous through Cenozoic of South America and the Paleogene of North America (e.g., Hecht, 1959; Hoffstetter and Rage, 1977; Hecht and LaDuke, 1997; Rage, 1998; Head et al., 2006; Hsiou et al., 2010). Among named taxa, Australophis was considered morphologically most similar to extant Anilius and Paleogene Hoffstetterella from Brazil (Goméz et al., 2008), however, the taxon shares a thickened zygosphene with Colombophis from the Miocene of Colombia and Venezuela (Hoffstetter and Rage, 1977; Head et al., 2006; Hsiou et al., 2010). No explicit phylogenetic topology yet exists for Australophis relative to other aniliids.

Constraining the first occurrence of Tropidophiidae is especially problematic because the composition of the clade is controversial in addition to the aforementioned discrepancies between molecular and morphological phylogenetic hypotheses of the taxon within Alethinophidia. Fossil taxa have been assigned to Tropidophiidae based on size and general shape (e.g., Dunnophis Hecht, 1959; Falseryx Szyndlar and Rage, 2003). Attempts to devise morphological diagnoses for recognizing fossils have been based on an explicit use of a monophyletic Tropidophiidae consisting of extant ((Tropidophis + Trachyboa) + Ungaliophiinae), following McDowell (1987). Both Molecular and morphological phylogenies have proposed paraphyly of this clade (e.g., Wilcox et al., 2002; Scanlon, 2006), however, and only a single distinct vertebral apomorphy, the presence of anteroposteriorly elongate, squared off ventral hypapophyses in precloacal vertebrae, occurs in Tropidophiidae = (Tropidophis + Trachyboa). The oldest record of the clade based on this character is Szyndlaria aureomontensis from the middle Eocene of Lissieu, France (Augé and Rage, 2010). Lissieu is considered to correspond to the late Lutetian stage (Augé and Rage, 2010), which is no younger than 41.2 Ma (Vandenberghe et al., 2012). The late Lutetian is here used as the minimum first occurrence of crown Tropidophiidae (Figure 1).

\section{BOINAE}

Node Calibrated. Divergence between total clades Boinae and Erycinae. 
Fossil Taxon. Titanoboa cerrejonensis Head et al., 2009.

Specimen. UF/IGM 1, precloacal vertebra.

Phylogenetic Justification. Titanoboa was united with Boinae on the basis of paracotylar fossae and foramina, straight, posteromedially angled interzygapophyseal ridges, and a vaulted posterior neural arch (Head et al., 2009).

Minimum Age. 58 Ma (Jaramillo et al., 2007).

Soft Maximum Age. 64 Ma (Woodburne et al., 2014).

Age Justification. The minimum age is the youngest age estimate for palynological zone CU-02, which contains the horizon from which Titanoboa fossils were recovered in the Cerrejón Formation of Colombia (Jaramillo et al., 2007; Head et al., 2009). The soft maximum age is the maximum age estimate for the Tiupampan SALMA (Woodburne et al., 2014), the oldest SALMA that includes the oldest reported records of boid snakes (Albino and Brizuela, 2014).

Discussion. Head et al. (2009) did not provide an explicit phylogenetic hypothesis for relationships of Titanoboa within Boinae, but united the taxon with Boa on the basis of paracotylar foramina morphology. Albino and Brizuela (2014) additionally noted a convex anterior zygosphene margin as a shared character of Titanoboa and extant Boa. Preliminary analysis of cranial elements suggests Titanoboa may be on the boine stem (Head et al., 2013). Molecular hypotheses place Boa as the sister taxon to all other boines (e.g., Burbrink, 2005). As a result, the occurrence of Titanoboa provides a minimum age for the boine-erycine (Pyron et al., 2013) divergence regardless of its position with respect to either Boa or the boine crown.

With respect to differences between the boine total clade calibration and known temporal ranges of crown Boinae and total clade Erycinae, the minimum age estimate for Titanoboa is only $\sim 8 \mathrm{Ma}$ older than the oldest extant boine lineage (see Corallus below), and is $\sim 16 \mathrm{Ma}$ older than the oldest described record for Boa (Albino, 1993) from the late Eocene (Barrancan 41.6-39.0 Ma Ré et al., 2010) of Argentina. The oldest diagnostic record of the erycine total clade is an apomorphic caudal vertebra from the early Eocene (Ypresian 55 Ma) of France (Rage, 1977), and implies at least a three million year unrecovered history between Erycinae and the minimum age of Titanoboa (Figure 1). The erycine record is dense through the Cenozoic of Europe (e.g., Hoffstetter and Rage, 1972; Szyndlar and Schleich, 1994), and caudal vertebral morphology is diagnostic at generic levels for both fossil taxa and the traditional split between extant Eryx and Gonglyophis (Sood, 1941; Hoffstetter and Rage, 1972; Rage, 1972; Szyndlar, 1994). Molecular analyses have recovered a paraphyletic Eryx with respect to Gongylophis (e.g., Pyron et al., 2013), however, which limits the use of caudal vertebral morphology in calibrating divergences within crown Erycinae.

\section{CORALLUS}

Node Calibrated. Divergence between total clade Corallus and the total clade (Chilabothrus+(Epicrates+Eunectes)).

Fossil Taxon. Corallus priscus Rage, 2001.

Specimen. DGM 1332-R precloacal vertebra (holotype).

Additional Materials. 74 precloacal vertebrae.

Phylogenetic Justification. Corallus priscus was assigned to the genus Corallus by Rage (2001) on the basis of: horizontal zygapophyseal articular facets, vaulted neural arch, and a tall neural spine. Additionally, C. priscus shares small, irregularly occurring paracotylar foramina with extant species of the genus. The combination of neural spine height and anteroposterior width, bi-angled interzygapophyseal ridges, and zygosphene shape make specimens of $C$. priscus indistinguishable from extant Corallus.

Minimum Age. 50.2 Ma.

Soft Maximum Age. 64 Ma (Woodburne et al., 2014).

Age Justification. Corallus priscus was recovered from fissure fills in travertine deposits at the locality of São José de Itaboraí in Rio de Janeiro, Brazil. The travertine layers are unconformably overlain by a basalt flow dated at $52.6 \pm 2.4 \mathrm{Ma}$ (Riccomini and Rodrigues-Francisco, 1992; Gomes Sant'Anna and Riccomini, 2001; Woodburne et al., 2014), which provides a hard minimum age for the taxon. The soft maximum age is the same as for Titanoboa.

Discussion. The fossil record of Corallus from Itaboraí represents the oldest record of an extant boid genus, and constrains the divergence of Neotropical Boinae to no younger than approximately $50 \mathrm{Ma}$. Molecular phylogenetic analyses place Boa constrictor as the sister taxon to Corallus + Chilabothrus+(Eunectes+ Epicrates) (Burbrink, 2005; Pyron et al., 2013; Reynolds et al., 2013, 2014). The first occurrence of Boa (Figure 1) and molecular topologies thus implies an approximately $19 \mathrm{Ma}$ unrecovered history of the genus between the maximum age of the Barrancan SALMA and the 
hard minimum age for Corallus (Head et al., 2012), assuming Titanoboa is a stem boine.

\section{EUNECTES}

Node Calibrated. Divergence between total clade Epicrates and Eunectes

Fossil Taxon. Eunectes stirtoni Hoffstetter and Rage, 1977.

Specimen. MNHN, VIV 7, right prootic.

Phylogenetic Justification. Eunectes stirtoni was erected and united with Eunectes within Boinae on the basis of diagnostic morphology including a shortened posterior margin behind the posterior trigeminal nerve foramen; an incomplete anterior trigeminal nerve foramen, a prominent, long "prootic process" (Tchernov et al., 2000) that forms the lateral edge of a narrow, well defined canal for the Vidian nerve (Hoffstetter and Rage, 1977).

Minimum Age. 12.375 Ma.

Soft Maximum Age. Indeterminate.

Age Justification. The type specimen of $E$. stirtoni was recovered from the Fish Bed of the Baraya member of the lower Villavieja Formation in the upper Magdalena River valley in central Colombia (Hoffstetter and Rage, 1977). ${ }^{40} \mathrm{Ar} / 39 \mathrm{Ar}$ dating of pumices from the underlying Monkey Beds and overlying San Francisco St. Beds of the Cerro Colorado Member of the Villavieja Formation constrains the ages of the Fish Bed to between 12.649 \pm 0.258 and $12.111 \pm 0.259 \mathrm{Ma}$ (Flynn et al., 1997). The Fish Bed directly overlies the Monkey Beds, and the minimum age estimate for the Monkey Beds, $12.486 \pm 0.111 \mathrm{Ma}$ (Flynn et al., 1997), is used here as the minimum estimate for the Eunectes-Epicrates divergence.

Discussion. Morphology of the prootic and an associated basisphenoid referred to Eunectes stirtoni are very similar in general shape and discrete characters to extant $E$. murinus (Hoffstetter and Rage, 1977). Other fossils referred to Eunectes have been recovered from the middlelate Miocene of periequatoral South America, including La Venta in Colombia (Hoffstetter and Rage, 1977; Hecht and LaDuke, 1997), Venezuela (Head et al., 2006; Hsiou and Albino, 2010), and Brazil (Hsiou and Albino, 2009, 2010). These records consist of isolated or associated precloacal vertebrae, and referral to genus is based on overall similarity instead of discrete apomorphies. The Villavieja Formation record of Eunectes provides a minimum divergence timing for both (Eunectes+Epicrates) and (Chilabothrus+(Epicrates+Eunectes)) (Reynolds et al., 2013). If E. stirtoni is most closely related to $E$. murinus, then the record described here minimally constrains divergence timings within the genus. Neogene fossil vertebrae have been compared with Epicrates (Hsiou and Albino, 2010), but this record cannot differentiate between that taxon and the newly recognized Chilabothrus, (Reynolds et al., 2013) and is not considered for calibration.

\section{CHARINIDAE}

Node Calibrated. Divergence between the total clades Ungaliophiinae (Ungaliophis+Exiliboa) sensu Pyron et al. (2014) and total clade Charininae (Charina+Lichanura) sensu Pyron et al. (2014).

Fossil Taxon. Calamagras weigeli.

Specimen. PTRM 19607, caudal vertebra.

Additional Materials. 19609, 19681, caudal vertebrae.

Phylogenetic Justification. Caudal vertebrae lacking paired haemapophyses, haemal keels present. This morphology is only present in Ungaliophis and Exiliboa among extant taxa (Smith, 2013).

Minimum Age. 35.2 Ma.

Soft Maximum Age. Indeterminate.

Age Justification. Minimum age is based on faunal correlation of Medicine Pole Hills fossil localities (Bowman County, North Dakota) with Flagstaff Rim localities (Natrona County, Wyoming), which are overlain by an ash layer (Ash B) that is $40 \mathrm{Ar} /$ ${ }^{39} \mathrm{Ar}$ dated at $35.41 \pm 0.14 \mathrm{Ma}$ (Obradovich et al., 1995). Smith (2011) recalculated the minimum estimate for the Medicine Pole Hills local fauna at 35.2 Ma.

Discussion. Numerous fossil taxa have been described as ungaliophiines, either explicitly as related to (Ungaliophis+Exiliboa) (e.g., Rage, 2008), or as part of a "Tropidophiidae" (Szyndlar et al., 2008) that is not supported by either morphological (Zaher, 1994) or molecular data (e.g., Wilcox et al., 2002). As noted by Smith (2013), the only fossil record that is united with (Ungaliophis+Exiliboa) on the basis of discrete apomorphies consists of isolated cloacal vertebrae assigned to Calamagras. Generic assignment of isolated vertebrae to Calamagras is problematic in that the generic and specific diagnoses for the taxon are do not include unique apomorphies or character combinations relative to other coeval, fossils, and are redundant with each other as described (Holman, 2000). Referral to Calamagras is tentatively followed here, but until the taxonomy and systematics of the genus can be unambiguously resolved, the record described in Smith 
(2013) must be used as the minimum divergence timing for the total clade, and stratigraphically older records of the genus (e.g., Hecht, 1959; Rage, 1977; Danilov and Averianov, 1999) should not be cited. Usage of Charinidae follows Pyron et al. (2014).

\section{CHARININAE}

Node Calibrated. Divergence between total clades Charina and Lichanura.

Fossil Taxon. Gen et sp. nov.

Specimen. UNSM 125562, caudal tailclub.

Phylogenetic Justification. UNSM 125562 is referred to the total clade of Charina (all fossil taxa more closely related to extant Charina than extant Lichanura) on the basis of the following caudal vertebral characters: 1) caudal tailclub composed of more than six vertebrae; 2) laterally expanded, lobate distal neural spine; 3) Anteriorly directed pterapophyses (="postzygapophyseal wing" of Szyndlar, 1994) present (Kluge, 1993; Szyndlar, 1994; Parham et al., 2012).

Minimum Age. 18.7 Ma (Tedford et al., 2004).

Soft Maximum Age. Indeterminate.

Age Justification. The minimum age is derived from radiometric dating of the Eagle Crag Ash, which overlies the top of the Harrison Formation, to $19.2 \pm 0.5 \mathrm{Ma}$ (MacFadden and Hunt, 1998; Tedford et al., 2004). Tedford et al. (2004, figure 6.2) indicate the top of the Harrison Formation may be as old as $20 \mathrm{Ma}$. Phylogenetic ambiguity in the fossil record of small boid snakes from North America (e.g., Holman, 2000 after Smith, 2013) greatly limits inference of a soft maximum as of this writing.

Discussion. The Charina+Ungaliophiinae divergence was previously calibrated at no younger than $16 \mathrm{Ma}$, based on a record of tailclubs from the Split Rock Formation of Wyoming (Parham et al., 2012). The Split Rock Formation is within the Hemingfordian NALMA, the top of which is dated at 16.0 Ma. Discovery of specimens referable to the total clade of (Ungaliophis+Exiliboa) from the Chadron Formation (Smith, 2013) extends that calibration point to $35.2 \mathrm{Ma}$. Ossified tailclubs referable to the Charina total clade from the Armstrong Ranch Quarry in the Harrison Formation of Sioux County Nebraska, extend the minimum age calibration of Charininae to $18.7 \mathrm{Ma}$, the youngest age estimate for the top of the Harrison Formation (Tedford et al., 2004). Lichanura has been reported from the middle Eocene Bridger Formation, based on synonymy of the fossil genus Paraepicrates to Lichanura (Hecht, 1959; Kluge, 1988). The basis for referral to Lichanura was based on two precloa- cal characters (narrow-based neural spine and shallow neural arch posteromedian notch, Kluge, 1988), neither of which is diagnostic for the genus. In the absence of an unambiguous fossil record for Lichanura, the Miocene fossil record of apomorphic caudal tailclubs is recognized as the oldest record for Charina and constrains the minimum divergence between it and Lichanura. Usage of Charininae follows Pyron et al. (2014).

\section{LOXOCEMIDAE}

Node Calibrated. Divergence between total clades Loxocemidae and Pythonidae.

Fossil Taxon. "Ogmophis" compactus.

Specimen. PTRM 19378, left quadrate.

Phylogenetic Justification. PTRM 19378 is united with Loxocemidae on the basis of: 1) dorsal head expanded into broad plate; 2) dorsal head lies wholly in saggital plane; 3) well-defined lip present on lateral side of dorsal margin (Smith, 2013).

Minimum Age. 35.2 Ma.

Soft Maximum Age. Indeterminate.

Age Justification. Justification follows the rationale for Charinidae above.

Discussion. Morphological phylogenetic analyses of snakes have traditionally recovered either monophyly of (Loxocemus + Xenopeltis) as the sistertaxon to all other macrostomatans (e.g., Lee and Scanlon, 2002; Scanlon, 2006), or as a paraphyletic grade at the base of Macrostomata (Tchernov et al., 2000). Molecular phylogenetic analyses recover Loxocemus as the sister taxon of Pythonidae (e.g., Slowinski and Lawson, 2002; Pyron et al., 2013). Based on molecular topologies, PTRM 19378 constrains (Loxocemidae+Pythonidae) to no younger than late Paleogene. Smith (2013) associated isolated cranial elements including PTRM 19378 with vertebrae assigned to the vertebral form genus Ogmophis based primarily on relative abundances of elements collected by dry-screening and surface collection from a single locality, PTRM V89002 (Smith, 2013). As with Calamagras (see above), the diagnosis (Holman, 2000) used to assign specimens to Ogmophis compactus by Smith (2013) is problematic because it does not include any individual apomorphies or a unique character combination for either the genus or species, following descriptions of other taxa in Holman (2000). Thus, while the generic assignment of Smith (2013) is tentatively accepted for the purposes of identifying PTRM 19378 in snake phylogeny (Figure 1), the taxonomic and systematic ambiguity of "Ogmophis", requires restricting the 
first occurrence of Loxocemidae to cranial remains described in Smith (2013), and not to stratigraphically older published records of the genus (Holman, 2000).

\section{MORELIA}

Node Calibrated. Divergence between Morelia and Liasis.

Fossil Taxon. Morelia riversleighensis Smith and Plane, 1985 vide Scanlon, 2001.

Specimen. QM F12926, right maxilla (holotype). "AR" is not listed as a formal collection abbreviation, but likely represents field numbers associated with specimens housed in the Queensland Museum.

Additional Materials. AR 13392, partial right mandible; AR 5658, premaxilla; AR 16880, left palatine. Other specimens are listed in Scanlon (2001).

Phylogenetic Justification. The hypodigm of $M$. riversleighensis is assigned to the genus on the basis of: 1) two teeth per side of the premaxilla; 2) anterior palatine teeth longer, thicker, and more vertical than posterior teeth; 3 ) deeply concave posterior margin of palatine choanal process; 4) concave anterior margin of premaxilla; 5) ventral openings of premaxilla channels posterior to tooth positions; and 6 maxillary lateral budges present (Scanlon, 2001, p. 6).

Minimum Age. $12.5 \mathrm{Ma}$.

Soft Maximum Age. Indeterminate.

Age Justification. Morelia riversleighensis was recovered from the Henk's Hollow Site in System C of the Riversleigh fossil sites (Scanlon, 2001). The minimum age estimate is based on faunal correlation between System C and the Bullock Creek Local Fauna (Travouillon et al., 2006; Travouillon et al., 2009, figure 1).

Discussion. Morelia riversleighensis was originally described as Montypythonoides riversleighensis (Smith and Plane, 1985), but was subsequently synonymized with Morelia by Kluge (1993). ScanIon (2001) provided a detailed description of Miocene pythonine fossils and synonymized Morelia antiqua from the middle Miocene Camfield Beds (Smith and Plane, 1985) with M. riversleighensis.

Other pythonine fossil records have been documented from the Neogene and Quaternary of Africa, Asia, Europe, and Australia (e.g., Portis, 1901; Hoffstetter, 1964; Rage, 1976; Thomas et al., 1982; Smith and Plane, 1985; Rage and Ginsburg, 1997; Ivanov, 2000; Scanlon, 2001; Scanlon and Mackness, 2002; Rage, 2003; Szyndlar and Rage, 2003; Head, 2005; Rage and Bailon, 2005; Head and Bell, 2008; Ivanov and Böhme, 2011).
Most records have been assigned to extant genera based on overall similarity of vertebral morphology. Python europaeus was erected using a precloacal vertebra as holotype (Szyndlar and Rage, 2003) on the justification of shared provenance with a partial palatine that had previously been assigned to the genus on the basis of an enclosed maxillary nerve foramen (Ivanov, 2000). An enclosed maxillary nerve foramen is plesiomorphic for pythonines, however (Kluge, 1993), and the character cannot differentiate between Python and other taxa. As a result, there is no other published record that can be unambiguously assigned to a crown genus or species on the basis of discrete apomorphy, despite very likely belonging to extant taxa.

Molecular phylogenetic analyses have resulted in paraphyly of multiple pythonine taxa, including Python and Morelia (Rawlings et al., 2008; Reynolds et al., 2014). As a result, the morphological topology incorporating $M$. riversleighensis (Scanlon, 2001) cannot be directly compared to molecular hypotheses. The Riversleigh and Camfield records do provide a minimum occurrence for divergence of Liasis relative to the grade of taxa currently and previously included in Morelia (Kluge, 1993; Reynolds et al., 2014). The Liasis-Morelia divergence calibrated here additionally constrains minimum divergence timings of Antaresia, Simalia, Aspidites, and Bothrochilus (Reynolds et al., 2014).

\section{DISCUSSION}

\section{Comparisons to Calibrated Nodes from Other Studies}

Taxa used to estimate hard minimum ages for nodes listed here are generally consistent with those employed by recent molecular phylogenetic analyses to temporally calibrate the deepest divergences in snakes: Sanders et al. (2010) included the same "Coniophis" record as part of their uniform prior calibration of the snake crown; Pyron and Burbrink (2012) calibrated the snake total clade using the Most Recent Common Ancestor (MRCA) within Toxicofera (see discussion of PanSerpentes in this analysis); and Pyron and Burbrink (2012) used pachyophiids, including Haasiophis, to calibrate the MRCA of Alethinophidia.

There have been limited attempts to use fossil to calibrate divergence timings within Boidae due to a lack of phylogenetic resolution and perceived taxonomic ambiguity in vertebral anatomy (see Sanders et al., 2010 for discussion). This study provides the most explicitly justified calibration points for Boidae Pythonidae, and other non- 
caenophidian macrostomatans by restricting calibration points to fossils that are diagnosable to extant genera (e.g., Corallus, Eunectes, Charina, Morelia), or are referable to higher clades on the basis of discrete, testable characters (e.g., Titanoboa, "Calamagras" weigeli, "Ogmophis" compactus). Importantly, none of the calibration points justified here unambiguously extend the boid or pythonid fossil records into the Cretaceous (Figure 1). Previous reports of Cretaceous "boids" have been based on fragmentary remains (e.g., Albino, 2000) and were used to establish Cretaceous-aged uniform priors for Boidae (Sanders et al., 2010). These records are no longer considered to represent Mesozoic records of basal macrostomatans (e.g., Albino and Brizuela, 2014), and although the total clade of Booidea (sensu Gauthier et al., 2012) can be calibrated to no younger than Maastrichtian based on the oldest record of Caenophidia (Figure 1 ), there are no definitive Mesozoic records of crown clades with Booidea.

\section{Implications of Revised Calibrations for Biogeographic Hypotheses}

Revised younger calibration points for Booidea will likely provide different divergence timings relative to previous studies that correlate molecular divergences with Cretaceous tectonic histories to infer a Gondwanan vicariant biogeographic mode for boid taxa (Noonan and Chippindale, 2006a, 2006b). Sanders et al. (2010) and Parham et al. (2012) previously identified multiple issues with calibration points in these studies, but specific differences with previous calibrations within Booidea require additional commentary. The minimum divergence timing between Charina and Exiliboa was calibrated to be greater than $55 \mathrm{Ma}$ by Noonan and Chippindale (2006b) based on the occurrence of the Paleogene taxon Dunnophis. There is no anatomical evidence linking Dunnophis to either taxon. Instead, the calibration using apomorphic characters in this analysis minimally constrains the divergence to no younger than $35.2 \mathrm{Ma}$ based on the occurrence of "Calamagras" weigeli. Neither this study nor Noonan and Chippindale (2006b) provides soft maxima for most calibrated nodes, but an approximately $20 \mathrm{Ma}$ contraction in minima presented here would almost certainly result in younger divergence estimates if incorporated. Similarly, the hard minimum for Booidea based on the stratigraphic distribution of Caenophidia presented here would be latest Cretaceous in age, whereas Noonan and Chippindale (2006b) provided a minimum of $>75 \mathrm{Ma}$ based on the occurrence of Dinilysia. Dinilysia is either a stem snake (Zaher and Scanferla, 2012) or a stem alethinophidian (Wilson et al., 2010), and therefore does not provide an accurate minimum age for the booid total clade (Sanders et al., 2010). A Maastrichtian minimum age for booids based on Caenophidia could be up to $10 \mathrm{Ma}$ younger than the minimum estimated from Dinilysia, further suggesting younger divergence dates if justified calibrations are employed.

The first occurrences of boids and pythonids greatly postdate the tectonic events that have been proposed to explain their modern distributions. Gondwanan fragmentation was initiated by the late Jurassic (Jokat et al., 2003), with separation and isolation of Africa by the end of the Early Cretaceous and Madagascar by the mid Late Cretaceous. While it may be tempting to invoke poor fossil record quality to explain this discrepancy, diverse fossil snake records of putative stem snakes and indeterminate taxa have been documented throughout Late Cretaceous deposits of South America (e.g., Apesteguía and Zaher, 2006; Albino and Brizuela, 2014; Hsiou et al., 2014), India (Rage and Prasad, 1992; Prasad and Rage, 1995; Rage et al., 2004; Wilson et al. 2010; Mohabey et al., 2011), and Madagascar (LaDuke et al, 2010; Pritchard et al., 2014). Recent discovery of extralimital distributions of boids based on the occurrence of the boine Rukwanyoka from the late Oligocene of Tanzania (McCartney et al., 2014) additionally confounds a Gondwanan vicariant signal with respect geographic distribution. This record may indicate that extant boid distributions result from Neogene or younger regional extinction instead of Cretaceous Gondwanan vicariance. Based on discrepancies between the fossil record and biogeographic events inferred from previous molecular divergence timings, a new set of divergence timing estimates, incorporating the explicitly justified records described here, will be required to assess the contribution of continental-scale vicariance to the distributions of extant booid snakes.

\section{ACKNOWLEDGMENTS}

For discussion and invitation to participate in the NESCent Fossil Calibrations Working Group, I thank J. Parham, D. Ksepka, and R. Irmis. I thank C. Bell for access to obscure literature. Reviews by D. Gower and an anonymous reviewer greatly improved the manuscript. 


\section{REFERENCES}

Albino, A.M. 1993. Snakes from the Paleocene and Eocene of Patagonia (Argentina): Paleoecology and coevolution with mammals. Historical Biology, 7:5169.

Albino, A.M. 2000. New record of snakes from the Cretaceous of Patagonia (Argentina). Geodiversitas, 22:247-253.

Albino, A.M. and Brizuela, S. 2014. An overview of the South American fossil squamates. The Anatomical Record, 297:349-368.

Alifanov, V.R. 2013. Desertiguana gobiensis gen. et sp. nov., a new lizard (Phrynosomatidae, Iguanomorpha) from the upper Cretaceous of Mongolia. Paleontological Journal, 47:417-424.

Apesteguía, S. and Zaher, H. 2006. A Cretaceous terrestrial snake with robust hindlimbs and a sacrum. Nature, 440:1037-1040.

Augé, M. and Rage, J.-C. 2006. Herpetofaunas from the upper Paleocene and lower Eocene of Morocco. Annales de Paléontologie, 92:235-253.

Augé, M. and Rage, J.-C. 2010. Squamate reptiles from the middle Eocene of Lissieu (France). A landmark in the middle Eocene of Europe. Geobios, 43:253-268.

Bell, C.J., Gauthier, J.A., and Bever, G.S. 2010. Covert biases, circularity, and apomorphies: A critical look at the North American Quaternary herpetofaunal stability hypothesis. Quaternary International, 217:30-36.

Bell, C.J., Head, J.J., and Mead, J.I. 2004. Synopsis of the herpetofauna from Porcupine Cave, p. 117-126. In Barnosky, A.D. (ed.), Biodiversity Response to Climate Change in the Middle Pleistocene. The Porcupine Cave Fauna from Colorado. University of California Press, Berkeley.

Bolet, A. and Evans, S.E. 2011. New material of the enigmatic Scandensia, an Early Cretaceous lizard from the Iberian Peninsula. Special Papers in Palaeontology, 86:99-108.

Bolkay, S.J. 1925. Mesophis nopcsai n.g. n.sp. ein neues, schlangenähnliches reptil aus der unteren Kreide (Neocom) von Bilek-Selista (Ost-Hercegovina). Glasnik zemaljskog Muzeja u Bosni i Hercegovini, Sarajevo, 37:125-135.

Braun, M. and Hirsch, F. 1994. Mid Cretaceous (AlbianCenomanian) carbonate platforms in Israel. Cuadernos de Geología, Ibérica, 18:59-81.

Burbrink, F.T. 2005. Inferring the phylogenetic position of Boa constrictor among the Boinae. Molecular Phylogenetics and Evolution, 34:167-180.

Burbrink, F.T. and Lawson, R. 2007. How and when did Old World rat snakes disperse in the New World? Molecular Phylogenetics and Evolution, 43:173-189.

Chalfia, Y. 1985. Saurorhamphus judeaensis (Salmoniformes: Enchodontidae), a new longirostrine fish from the Cretaceous (Cenomanian) of Ein-Yabrud, near Jerusalem. Journal of Vertebrate Paleontology, 5:181-193.
Chalfia, Y. and Tchernov, E. 1982. Pachyamia latimaxillaris, new genus and species (Actinopterygii: Amiidae), from the Cenomanian of Jerusalem. Journal of Vertebrate Paleontology, 2:269-285.

Cifelli, R.L., Kirkland, J.I., Weil, A., Deino, A.L., and Kowallis, B.J. 1997. High-precision ${ }^{40} \mathrm{Ar} /{ }^{39} \mathrm{Ar}$ geochronology and the advent of North America's Late Cretaceous terrestrial fauna. Proceedings of the National Academy of Sciences, USA, 94:1116311167.

Conrad, J.L. 2008. Phylogeny and systematics of Squamata (Reptilia) based on morphology. Bulletin of the American Museum of Natural History, 310:1-182.

Conrad, J.L., Ast, J.C., Montanari, S., and Norell, M.A. 2011. A combined evidence phylogenetic analysis of Anguimorpha (Reptilia: Squamata). Cladistics, 27:230-277.

Conrad, J.L. and Norell, M.A. 2007. A complete Late Cretaceous iguanian (Squamata, Reptilia) from the Gobi and identification of a new iguanian clade. American Museum Novitates, 3584:1-47.

Cuny, G., Jaeger, J.-J., Mahboubi, M., and Rage, J.-C. 1990. Les plus anciens Serpents (Reptilia, Squamata) connus. Mise au point sur l'âge géologique des Serpentes de la partie moyenne du Crétacé. Comptes rendus des séances de l'Académie des Sciences, Paris, Série II, 311:1267-1272.

Danilov, I.G. and Averianov, A.O. 1999. A new species of Calamagras Cope 1873 (Serpentes, Boidae, Erycinae) from the early Eocene of Kirghizia. Geodiversitas, 21:85-91.

Dingus, L., Clarke, J., Scott, G.R., Swisher, C.C. III, Chiappe, L M., and Coria, R.A. 2000. Stratigraphy and magnetostratigraphic/faunal constraints for the age of sauropod embryo-bearing rocks in the Neuquén Group (Late Cretaceous, Neuquén Province, Argentina). American Museum Novitates, 3290:1-11.

Evans, S.E. 1994. A new anguimorph lizard from the Jurassic and lower Cretaceous of England. Palaeontology, 37:33-49.

Evans, S.E. and Barbadillo, L.J. 1999. A short-limbed lizard from the lower Cretaceous of Spain. Special Papers in Palaeontology, 60:73-85.

Evans, S.E. and Chure, D.J. 1998. Upper Jurassic lizards from the Morrison Formation of Dinosaur National Monument, Utah, p. 151-159. In Gillette, D. (ed.), Vertebrate Paleontology in Utah. Miscellaneous Publication 99-1, Utah Geological Survey, Salt Lake City.

Evans, S.E., Wang, Y., and Li, C. 2005. The Early Cretaceous lizard genus Yabeinosaurus from China: Resolving and enigma. Journal of Systematic Palaeontology, 3:319-335.

Flynn, J.J., Guerrero, J., and Swisher, C.C. III. 1997. Geochronology of the Honda Group, p. 44-59. In Kay, R.F., Madden, R.H., Cifelli, R. L., and Flynn, J.J. (eds.), Vertebrate Paleontology in the Neotropics. Smithsonian Institution Press, Washington, D.C. 
Gao, K. and Hou, L. 1995. Iguanians from the Upper Cretaceous Djadochta Formation, Gobi Desert, China. Journal of Vertebrate Paleontology, 15:57-78.

Gao, K. and Norell, M.A. 2000. Taxonomic composition and systematics of Late Cretaceous lizard assemblages from Ukhaa Tolgod and adjacent localities, Mongolian Gobi Desert. Bulletin of the American Museum of Natural History, 249:1-118.

Gardner, J.D. and Cifelli, R.L. 1999. A primitive snake from the Cretaceous of Utah. Special Papers in Palaeontology, 60:87-100.

Gauthier, J.A., Kearney, M., Maisano, J.A., Rieppel, O., and Behlke, A.D.B. 2012. Assembling the squamate tree of life: perspectives from the phenotype and the fossil record. Bulletin of the Peabody Museum of Natural History, 53:3-308.

Gomes Sant'Anna, L. and Riccomini, C. 2001. Cimentação hidrothermal em depósitos sedimentares Paleogênicos do rift continental do sudeste do Brasil: mineralogia e relaçöes tectônicas. Revista Brasileira Geociências, 31:231-240.

Gómez, R.O., Báez, A.M., and Rougier, G.W. 2008. An anilioid snake from the Upper Cretaceous of northern Patagonia. Cretaceous Research, 29:481-488.

Gower, D.J., Vidal, N., Spinks, J.N., and McCarthy, C.J. 2005. The phylogenetic position of Anomochilidae (Reptilia: Serpentes): first evidence from DNA sequences. Journal of Zoological Systematics and Evolutionary Research, 43:315-320.

Haas, G. 1979. On a new Snakelike Reptile from the Lower Cenomanian of Ein Jabrud, near Jerusalem. Bulletin du Muséum national d'Histoire Naturelle de Paris, 1C:51-64.

Haas G. 1980. Remarks on a new ophiomorph reptile from the lower Cenomanian of Ein Jabrud, Israel 177-192. In Jacobs, L.L. (ed.), Aspects of Vertebrate History. Museum of Northern Arizona Press, Flagstaff.

Head, J.J. 2005. Snakes of the Siwalik Group (Miocene of Pakistan): systematics and relationship to environmental change. Palaeontologia Electronica 8.1.16A:33pp, 2.5MB; http://palaeo-electronica.org/ paleo/2005_1/head18/issue1_05.htm

Head, J.J. and Bell, C.J. 2008. Snakes from Lemudong'o, Kenya Rift Valley. Kirtlandia, 56:177-179.

Head, J.J., Bloch, J.I., Hastings, A.K., Bourque, J.R., Cadena, E.A., Herrera, F.A., Polly, P.D., and Jaramillo, C.A. 2009. Giant boid snake from the Paleocene neotropics reveals hotter past equatorial temperatures. Nature, 457:715-717.

Head, J.J., Bloch, J.I., Moreno-Bernal, J., Rincon Burbano, A., and Bourque, J. 2013. Cranial osteology, body size, systematics, and ecology of the giant Paleocene snake Titanoboa cerrejonensis. Journal of Vertebrate Paleontology, 33(suppl.):140-141.
Head, J.J., Rincon, A., Suarez, C. Montes, C., and Jaramillo C. 2012. Evidence for American interchange during the earliest Neogene: Boa from the Miocene of Panama. Journal of Vertebrate Paleontology, 32:1328-1334.

Head, J.J., Sánchez-Villagra, M.R., and Aguilera, O. 2006. Fossil snakes from the Neogene of Venezuela (Falcón State). Journal of Systematic Palaeontology, 4:233-240.

Hecht, M.K. 1959. Amphibians and Reptiles 130-146. In McGrew, P.O. (ed.), The geology and paleontology of the Elk Mountain and Tabernacle Butte area, Wyoming. Bulletin of the American Museum of Natural History, 117:1-176.

Hecht, M.K. and LaDuke, T.C. 1997. Limbless tetrapods of the La Venta Fauna, Colombia, p. 95-99. In Kay, R.F., Madden, R.H., Cifelli, R. L., and Flynn, J.J. (eds.), Vertebrate Paleontology in the Neotropics. Smithsonian Institution Press, Washington, D.C.

Heise, P.J., Maxson, L.R., Dowling, H.G., and Hedges, S.B. 1996. Higher-level snake phylogeny inferred from mitochondrial DNA sequences of 12S rRNA and $16 S$ rRNA genes. Molecular Phylogenetics and Evolution, 12:259-265.

Hoffstetter, R. 1959. Un serpent terrestre dans le Crétacé du Sahara. Bulletin de la Société géologique de France, Paris, 7:897-902.

Hoffstetter, R. 1964. Les serpents du Néogène du Pakistan (couches des Siwaliks). Bulletin de la Société Géologique de France, Série 7, 6:467-474.

Hoffstetter, R. 1967. Coup d'œil sur les sauriens (lacertiliens) des Couches de Purbeck (Jurassiqu supérieur D’Angleterre) (Résumé d'un mémoire). Colloques Internationaux du Centre National de la Recherche Scientifique, 163:349-371.

Hoffstetter, R. and Gasc, J.-P. 1969. Vertebrae and ribs of modern reptiles, p. 201-310. In Gans, C. (ed.), Biology of the Reptilia, Volume 1: Morphology. Academic Press, London.

Hoffstetter, R. and Rage J.-C. 1972. Les Erycinae fossiles de France (Serpentes, Boidae). Compréhension et histoire de la sous-famille. Annales de Paléontologie (Vertébrés), 58:1-124.

Hoffstetter, R. and Rage J.-C. 1977. Le gisement de vertébrés Miocènes de La Venta (Colombie) et sa faune de serpents. Annales de Paléontologie, 63:161-190.

Holman, J.A. 2000. The fossil snakes of North America. Indiana University Press, Indianapolis.

Hsiou, A.S. and Albino, A.M. 2009. Presence of the genus Eunectes (Serpentes, Boidae) in the Neogene of Southwestern Amazonia, Brazil. Journal of Herpetology, 43:612-619.

Hsiou, A.S. and Albino, A.M. 2010. New snake remains from the Miocene of northern South America. Herpetological Journal, 20:249-259. 
Hsiou, A.S., Albino, A.M., and Ferigolo, J. 2010. Reappraisal of the south American Miocene snakes of the genus Colombophis, with description of a new species. Acta Palaeontologica Polonica, 55:365-279.

Hsiou, A.S., Albino, A.M., Medeiros, M.A., and Santos, R.A.B. 2014. The oldest Brazilian snakes from the early Late Cretaceous (Cenomanian). Acta Palaeontologica Polonica, 59:635-642.

Hsiou, A.S., Santos, R.A.B., and Medeiros, M.A. 2009. First record of Madtsoiidae (Serpentes) from the Middle Cretaceous (Albian-Early Cenomanian) of Brazil. Abstracts (Livro de Resumos) of the 21st Congresso Brasileiro de Paleontologia, 90-90.

Ivanov, M. 2000. Snakes of the lower/middle Miocene transition at Vieux Collonges (Rhône, France), with comments on the colonisation of western Europe by colubroids. Geodiversitas, 22:559-588.

Ivanov, M. and Böhme, M. 2011. Snakes from Griesbeckerzell (Langhian, Early Badenian), North Alpine Foreland Basin (Germany), with comments on the evolution of snake faunas in Central Europe during the Miocene Climatic Optimum. Geodiversitas, 33:411-449.

Jaramillo, C.A., Bayona, G., Pardo-Trujillo, A., Rueda, M., Torres, V., Harrington, G.J., and Mora, G. 2007. The palynology of the Cerrejón Formation (upper Paleocene) of northern Colombia. Palynology, 31:153-189.

Jokat, W., Boebel, T., Köing, M., and Meyer, U. 2003. Timing and geometry of early Gondwana breakup. Journal of Geophysical Research, 108(B9):2428. doi:10.1029/2002JB001802.

Kluge, A.G. 1988. Relationships of the Cenozoic boine snakes Paraepicrates and Pseduoepicrates. Journal of Vertebrate Paleontology, 8:229-230.

Kluge, A.G. 1993. Aspidites and the phylogeny of pythonine snakes. Records of the Australian Museum Supplement, 19:1-77.

LaDuke, T.C., Krause, D.W., Scanlon, J.D., and Kley, N.J. 2010. A Late Cretaceous (Maastrichtian) snake assemblage from the Maevarano Formation, Mahajanga Basin, Madagascar. Journal of Vertebrate Paleontology, 30:109-138.

Lawson, R., Slowinski, J.B., and Burbrink, F.T. 2004. A molecular approach to discerning the phylogenetic placement of the enigmatic snake Xenophidion schaeferi among the Alethinophidia. Journal of Zoology, London, 263:285-294.

Lawson, R., Slowinski, J B., Crother, B.I., and Burbrink, F.T. 2005. Phylogeny of the Colubroidea (Serpentes): New evidence from mitochondrial and nuclear genes. Molecular Phylogenetics and Evolution, 37:581-601.

Leanza, H.A., Apesteguía, S., Novas, F.E., and de la Fuente, M.S. 2004. Cretaceous terrestrial beds from the Nequén Basin (Argentina) and their tetrapod assemblages. Cretaceous Research, 25:61-87.

Lee, M.S.Y. and Scanlon, J.D. 2002. Snake phylogeny based on osteology, soft anatomy and ecology. Biological Reviews, 77:333-401.
Longrich, N.R., Bhullar, B.-A., and Gauthier, J.A. 2012. A transitional snake from the Late Cretaceous period of North America. Nature, 488:205-208.

MacFadden, B.J. and Hunt, R.M. 1998. Magnetic polarity stratigraphy and correlation of the Arikaree Group, Arikareean (late Oligocene-early Miocene) of northwestern Nebraska, p. 143-165. In Terry, D.O. jr., LaGarry, H.E., and Hunt, R.M. jr. (eds.), Depositional environments, lithostratigraphy, and biostratigraphy of the White River and Arikaree groups (Late Eocene to Early Miocene, North America), Boulder, Colorado. Geological Society of America Special Paper, 325.

McCartney, J.A., Stevens, N.J., and O'Connor. P.M. 2014. The Earliest Colubroid-Dominated Snake Fauna from Africa: Perspectives from the Late Oligocene Nsungwe Formation of Southwestern Tanzania. PLoS ONE 9(3): e90415. doi:10.1371/journal.pone.0090415.

McDiarmid, R.W., Campbell, J.A., and Touré, T's.A. 1999. Snake Species of the World. A Taxonomic and Geographic Reference, Volume 1. The Herpetologists' League, Washington.

McDowell, S.B. 1987. Systematics, p. 3-50. In: Seigel, R.A., Collins, J.T., and Novak, S.S. (eds.), Snakes: ecology and evolutionary biology. Macmillan, New York.

Mohabey, D., Head, J.J., and Wilson, J.A. 2011. A new species of the snake genus Madtsoia from the Cretaceous of India and its paleobiogeographical implications. Journal of Vertebrate Paleontology, 33:588595.

Nessov, L.A., Zhegallo, V.I., and Averianov, A.O. 1998. A new locality of Late Cretaceous snakes, mammals and other vertebrates in Africa (western Libya). Annales de Paléontologie, Paris, 84:265-274.

Noonan, B.P. and Chippindale, P.T. 2006a. Dispersal and vicariance: The complex evolutionary history of boid snakes. Molecular Phylogenetics and Evolution, 40:347-358.

Noonan, B.P. and Chippindale, P.T. 2006b. Vicariant origin of Malagasy reptiles supports Late Cretaceous Antarctic land bridge. The American Naturalist, 168:730-741.

Nopcsa, F. 1923. Eidolosaurus und Pachyophis. Zwei neue Neocom-Reptilien. Palaeontographica, 65:99154.

Nopcsa, F. 1925. Die Symoliophis-Reste. In, Ergbenisse der Forschungsreisen Prof. E. Stromers in den Wüsten Ägyptens, II. Abhandlungen der Bayerischen Akademie der Wissenschaften, Mathematisch- naturwissenschaftliche Abteilung, München, 30:1-27.

Obradovich, J.D., Evanoff, E., and Larson, E.E. 1995. Revised single-crystal laser-fusion ${ }^{40} \mathrm{Ar} /{ }^{39} \mathrm{Ar}$ ages of Chadronian tuffs in the White River Formation of Wyoming. Geological Society of America, Abstracts with Programs, 27:77-78. 
Ogg, J.G., Hinnov, L.A., and Huang, C. 2012. Cretaceous, p. 793-854. In Gradstein, F., Ogg, J. G., Schmitz, M., and Ogg, G (eds.), The Geologic Time Scale 2012. Elsevier, Amsterdam.

Palci, A., Caldwell, M.W., and Nydam, R.L. 2013. Reevaluation of the anatomy of the Cenomanian (Upper Cretaceous) hind-limbed marine fossil snakes Pachyrhachis, Haasiophis, and Eupodophis. Journal of Vertebrate Paleontology, 33:1328-1342.

Parham, J.F., Donoghue, P.C.J., Bell, C.J., Calway, T.D., Head, J.J., Holroyd, P.A., Inoue, J.G., Irmis, R.B., Joyce, W.G., Ksepka, D.T., Patańe, J.S.L.N., Smith, D., Tarver, J.E., van Tuinen, M., Yang, Z., Angielczyk, K.D., Greenwood, J., Hipsley, C.A., Jacobs, L.L., Makovicky, P.J., Müller, J., Smith, K.T., Theodor, J.M., Warnock, R.C.M., and Benton, M.J. 2012. Best practices for applying paleontological data to molecular divergence dating analyses. Systematic Biology, 61:346-359.

Portis, A. 1901. Palaeopython sardus Pot. Nuovo Pitonide del Miocene medio della Sardegna. Bollettino della Società Geologica Italiana, 20:247-253.

Prasad, G.V.R. and Rage, J.-C. 1995. Amphibians and squamates from the Maastrichtian of Naskal, India. Cretaceous Research, 16:95-107.

Pritchard, A.C., McCartney, J.A., Krause, D.W., and Kley, N.J. 2014. New snakes from the Upper Cretaceous (Maastrichtian) Maevarano Formation, Mahajanga Basin, Madagascar. Journal of Vertebrate Paleontology, 34:1080-1093.

Pyron, R.A. and Burbrink, F.T. 2012. Extinction, ecological opportunity, and the origins of global snake diversity. Evolution, 66:163-178.

Pyron, R.A., Burbrink, F.T., and Wiens, J.J. 2013. A phylogeny and revised classification of Squamata, including 4161 species of lizards and snakes. BMC Evolutionary Biology, 3:93.

Pyron, R.A., Reynolds, R.G., and Burbrink, F.T. 2014. A taxonomic revision of boas (Serpentes: Boidae). Zootaxa, 3846:249-260.

Rage, J.-C. 1972. Eryx Daudin et Gongylophis Wagler (Serpentes, Boidae) Étude ostéologique. Bulletin du Muséum National D'Histoire Naturelle $3^{\mathrm{e}}$ Série, 78:893-899.

Rage, J.-C. 1976. Les squamates du Miocène de Béni Mellal, Maroc. Géologie Méditerranéene, 2:57-70.

Rage, J.-C. 1977. An erycine snake (Boidae) of the genus Calamagras from the French lower Eocene, with comments on the phylogeny of the Erycinae. Herpetologica, 33:459-463.

Rage, J.-C. 1984. Encyclopedia of Paleoherpetology, part 11, Serpentes. Gustav Fischer Verlag, Stuttgart.

Rage, J.-C. 1988. Un serpent primitif (Reptilia, Serpentes) dans le Cénomanien (base du Crétacé supérieur). Comptes rendus des séances de l'Académie des Sciences, Paris, II, 307:1027-1032.

Rage, J.-C. Fossil snakes from the Paleocene of São José de Itaboraí, Brazil. Part I. Madtsoiidae, Aniliidae. Palaeovertebrata, 27:109-144.
Rage, J.-C. 2001. Fossil snakes from the Paleocene of São José de Itaboraí, Brazil. Part II. Boidae. Palaeovertebrata, 30:111-150.

Rage, J.-C. 2003. Squamate reptiles from the early Miocene of Arrisdrift (Namibia) p. 43- 50. In Senut, B. and Pickford, M. (eds.), Geology and Palaeobiology of the central and southern Namib. Vol. 2: Palaeontology of the Orange River valley, Namibia. Memoir of the Geology Survey of Namibia (Ministry of Mines and Energy, Windhoeck), 19.

Rage, J.-C. 2008. Fossil snakes from the Paleocene of São José de Itaboraí, Brazil. Part III. Ungaliophiinae, boids incertae sedis, and Caenophidia. Summary, update, and discussion of the snake fauna from the locality. Palaeovertebrata, 36:37-73.

Rage, J.-C. and Bailon, S. 2005. Amphibians and squamate reptiles from the late early Miocene (MN 4) of Béon 1 (Montréal-du-Gers, southwestern France). Geodiversitas, 27:413-441.

Rage, J.-C. and Escuillié, F. 2000. Un nouveau serpent bipède du Cénomanien (Crétacé). Implications phylétiques. Comptes rendus des séances de l'Académie des Sciences, Paris, Ila, 330:513-520.

Rage, J.-C. and Escuillié, F. 2003. The Cenomanian: stage of hindlimbed snakes. Carnets de Géologie, 2002:1-11.

Rage, J.-C. and Ginsburg, L. 1997. Amphibians and squamates from the early Miocene of Li Mae Long, Thailand: The richest and most diverse herpetofauna from the Cainozoic of Asia, p. 167-168. In Rocek, Z. and Hart, S. (eds.), Herpetology '97. Ministry of Environment of the Czech Republic, Prague.

Rage, J.-C. and Prasad, G.V.R. 1992. New snakes from the Late Cretaceous (Maastrichtian) of Naskal, India. Neues Jahrbuch für Geologie und Paläontologie, Abhandlungen, 187:83-97.

Rage, J.-C., Prasad, G.V.R., and Bajpai, S. 2004. Additional snakes from the uppermost Cretaceous (Maastrichtian) of India. Cretaceous Research, 25:425-434.

Rage, J.-C. and Werner, C. 1999. Mid-Cretaceous (Cenomanian) snakes from Wadi Abu Hashim, Sudan: The earliest snake assemblage. Palaeontologia Africana, 35:85-110.

Rawlings, L.H., Rabosky, D.L., Donnellan, S.C., and Hutchinson, M.N. 2008. Python phylogenetics: inference from morphology and mitochondrial DNA. Biological Journal of the Linnean Society, 93:603-619.

Ré, R.H., Bellosi, E.S., Heizler, M., Vilas, J.F., Madden, R.H., Carlini, A.A., Kay, R.F., and Vucetich, M.G. 2010. A geochronology for the Sarmiento Formation at Gran Barranca, p. 46-58. In Madden, R.H., Carlini, A.A., Vucetich, M.G., and Kay, R.F. (eds.), The Paleontology of Gran Barranca. Cambridge University Press, New York.

Reynolds, R.G., Niemiller, M.L., Hedges, S.B., Dornburg, A., Puente-Rolón, A.R., and Revell, L.J. 2013. Molecular phylogeny and historical biology of West Indian snakes (Chilabothrus). Molecular Phylogenetics and Evolution, 68:461-470. 
Reynolds, R.G., Niemiller, M.L., and Revell, L.J. 2014. Toward a tree-of-life for the boas and pythons: Multilocus species-level phylogeny with unprecedented taxon sampling. Molecular Phylogenetics and Evolution, 71:201-213.

Riccomini, C. and Rodrigues-Francisco, B.H. 1992. Idade potássio-argônio do derrame de ankaramito da Bacia de Itaboraí, Rio de Janeiro, Brasil: implicações tectônicas, p. 469- 470. In SBG, Congresso Brasileiro de Geologia 37, São Paulo, Boletim de Resumos Expandidos.

Rieppel, O., Zaher, H., Tchernov, E., and Polcyn, M.J. 2003. The anatomy and relationships of Haasiophis terrasanctus, a fossil snake with well-developed hind limbs from the mid-Cretaceous of the Middle East. Journal of Paleontology, 77:536-558.

Sanders, K.L., Mumpuni, Hamidy, A., Head, J.J., and Gower, D.J. 2010. Phylogeny and divergence times of filesnakes (Acrochordus): Inferences from morphology, fossils and three molecular loci. Molecular Phylogenetics and Evolution, 56:857-867.

Scanlon, J.D. 2001. Montypythonoides: the Miocene snake Morelia riversleighensis (Smith and Plane, 1985) and the geographical origin of pythons. Memoirs of the Association of Australasian Palaeontologists, 25:1-35.

Scanlon, J.D. 2006. Skull of the large non-macrostomatan snake Yurlunggur from the Australian OligoMiocene. Nature, 439:839-842.

Scanlon, J.D. and Mackness, B.S. 2002. A new giant python from the Pliocene Bluff Downs Local Fauna of northeastern Queensland. Alcheringa, 25:425-437.

Schiebout, J.A., Rigsby, C.A., Rapp, S.D., Hartnell, J.A., and Standhardt, B.R. 1987. Stratigraphy of the Cretaceous-Tertiary and Paleocene-Eocene transition rocks of Big Bend National Park, Texas. The Journal of Geology, 95:359-375.

Slowinski, J.B. and Lawson, R. 2002. Snake phylogeny: evidence from nuclear and mitochondrial genes. Molecular Phylogenetics and Evolution, 24:194-202.

Smith, K.T. 2011. The evolution of mid-latitude faunas during the Eocene: late Eocene lizards of the Medicine Pole Hills reconsidered. Bulletin of the Peabody Museum of Natural History, 52:3-105.

Smith, K.T. 2013. New constraints on the evolution of the snake clades Ungaliophiinae, Loxocemidae and Colubridae (Serpentes), with comments on the fossil history of Erycine boids in North America. Zoologischer Anzeiger, 252:157-182.

Smith, M.J. and Plane, M. 1985. Pythonine snakes (Boidae) from the Miocene of Australia. BMR Journal of Australian Geology \& Geophysics, 9:19l-195.

Sood, M.S. 1941. The caudal vertebrae of Eryx johnii (Russell). Proceedings of the Indian Academy of Sciences, 14:390-394.

Standhardt, B.R. 1986. Vertebrate paleontology of the Cretaceous/Tertiary transition of Big Bend National Park, Texas. Ph.D. dissertation, Department of Geology, Louisiana State University, USA.
Stejneger, L. 1907. Herpetology of Japan and adjacent territory. Bulletin of the United States National Museum, 58:1-577.

Szyndlar, Z. 1994. Oligocene snakes of southern Germany. Journal of Vertebrate Paleontology, 14:24-37.

Szyndlar, Z. and Rage, J.-C. 2003. Non-erycine Booidea from the Oligocene and Miocene of Europe. Institute of Systematics and Evolution of Animals, Polish Academy of Sciences, Kraków.

Szyndlar, Z. and Schleich, H.-H. 1994. Two species of the genus Eryx (Serpentes: Boidae: Erycinae) from the Spanish Neogene with comments on the past distribution of the genus in Europe. Amphibia-Reptilia, 15:233-248.

Szyndlar, Z., Smith, R., and Rage, J.-C. 2008. A new dwarf boa (Serpentes, Booidea, "Tropidophiidae") from the Early Oligocene of Belgium: a case of the isolation of Western European snake faunas. Zoological Journal of the Linnaean Society, 152:393-406.

Tchernov, E., Rieppel, O., Zaher, H., Polcyn, M.J., and Jacobs, L.L. 2000. A fossil snake with limbs. Science, 287:2010-2012.

Tedford, R H., Albright, B. III, Barnosky, A.D., Ferrusquia-Villafranca, I., Hunt, R.M. jr., Storer, J.E., Swisher, C.C. III, Voorhies, M.R., Webb, S.D., and Whistler, D.P. 2004. Mammalian Biochronology of the Arikareean Through Hemphillian Interval (Late Oligocene Through Early Pliocene Epochs), p. 169-231. In Woodburne, M.O. (ed.), Late Cretaceous and Cenozoic Mammals of North America: Biostratigraphy and Geochronology. Columbia University Press, New York.

Thomas, H., Sen, S., Khan, M., Battail, B., and Ligabue, G. 1982. The Lower Miocene Fauna of Al-Sarrar (Eastern Province, Saudi Arabia). Atlal 5:109-136.

Townsend, T.M., Larson, A., Louis, E., and Macey, J.R. 2004. Molecular phylogenetics of Squamata: The position of snakes, amphisbaenians, and dibamids, and the root of the squamate tree. Systematic Biology, 53:735-757.

Travouillon, K.J., Archer, M., Hand, S.J., and Godthelp, H. 2006. Multivariate analyses of Cenozoic mammalian faunas from Riversleigh, north-western Queensland. Alcheringa Special Issue, 1:323-349.

Travouillon, K.J., Legendre, S., Archer, M., and Hand, S.J. 2009. Palaeoecological analysis of Riversleigh's Oligo-Miocene sites: implications for Oligo-Miocene climate change in Australia. Palaeogeography, Palaeoclimatology, Palaeoecology, 276:24-37.

Vandenberghe, N., Hilgen, F.J., and Speijer, R.P. 2012. The Paleogene Period, p. 855-921. In Gradstein, F., Ogg, J., Schmitz, M., and Ogg, G. (eds.), The Geologic Time Scale 2012. Elsevier Press, Amsterdam.

Vidal, N. and David, P. 2004. New insights into the early history of snakes inferred from two nuclear genes. Molecular Phylogenetics and Evolution, 31:783-787. 
Vidal, N. and Hedges, S.B. 2002. Higher-level relationships of snakes inferred from four nuclear and mitochondrial genes. Comptes Rendus Biologies, 325:977-985.

Vidal, N. and Hedges, S.B. 2004. Molecular evidence for a terrestrial origin of snakes. Proceedings of the Royal Society of London, Series B. (Suppl.), 271:S226-S229.

Vidal, N. and Hedges, S.B. 2005. The phylogeny of squamate reptiles (lizards, snakes, and amphisbaenians) inferred from nine nuclear protein-coding genes. Comptes Rendus Biologies, 328:1000-1008.

Vidal, N. and Hedges, S.B. 2009. The molecular evolutionary tree of lizards, snakes, and amphisbaenians. Comptes Rendus Biologies, 332:129-139.

Vullo, R., Rage, J.-C., and Neraudeau, D. 2011. Anuran and squamates remains from the Cenomanian (Late Cretaceous) of Charentes, western France. Journal of Vertebrate Paleontology, 31:279-291.

Wiens, J.J., Hutter, C.R., Mulcahy, D.G., Noonan, B.P., Townsend, T.M., Sites, J.W. jr., and Reeder, T.W. 2012. Resolving the phylogeny of lizards and snakes (Squamata) with extensive sampling of genes and species. Biology Letters, 8:1043-1046.

Wiens, J.J., Kuczynski, C.A., Townsend, T., Reeder, T.W., Mulcahy, D.G., and Sites, J.W. jr. 2010. Combining phylogenomics and fossils in higher-level squamate reptile phylogeny: molecular data change the placement of fossils. Systematic Biology, 59:674688.
Wilcox, T.P., Zwickl, D.J., Heath, T.A., and Hillis, D.M. 2002. Phylogenetic relationships of the dwarf boas and a comparison of Bayesian and bootstrap measures of phylogenetic support. Molecular Phylogenetics and Evolution. 25:361-371.

Wilson, J.A., Mohabey, D., Peters, S., and Head, J.J. 2010. Predation upon hatchling sauropod dinosaurs by a new basal snake from the Late Cretaceous of India. PLOS Biology, 8: e1000322. doi: 10.1371/journal.pbio. 1000322 .

Woodburne, M.O., Goin, F.J., Bond, M., Carlini, A.A., Gelfo, J.N., López, G.M., Iglesias, A., and Zimicz, A.N. 2014. Paleogene land mammal faunas of South America: a response to global climate change and indigenous floral diversity. Journal of Mammalian Evolution, 21:1-73.

Zaher, H. 1994. Les Tropidopheoidea (Serpentes; Alethinophidia) sont-ils réellement monophylétiques? Arguments en faveur de leur polyphylétisme. Comptes Rendus des séances de l'Académie des Sciences (Paris), Sciences de la vie, 317:471-478.

Zaher, H. and Rieppel, O. 1999. Tooth implantation and replacement in squamates, with special reference to mosasaur lizards and snakes. American Museum Novitates, 3271:1-19.

Zaher, H. and Scanferla, C.A. 2012. The skull of the upper Cretaceous snake Dinilysia patagonica SmithWoodward, 1901, and its phylogenetic position revisited. Zoological Journal of the Linnaean Society, 164:194-238. 